\title{
Protective Effect of Garcinia kola Seed and Honey Mixture against Cadmium-Induced Hepatotoxicity in Wistar Albino Rats
}

\author{
D.G. Tamuno-Emine ${ }^{1}$, A. F. Anyia ${ }^{2}$ \\ ${ }^{1}$ Department of Medical Laboratory Science (Chemical Pathology specialty), Rivers State University of Science and Technology, Port \\ Harcourt \\ ${ }^{2}$ Department of Chemical Pathology, Faculty of Basic Sciences, College of Health Science, University of Port Harcourt.
}

\begin{abstract}
Traditional African herbs, plants and fluid have been reported to exhibit therapeutic, curative and protective effect against sicknesses, diseases and even poisonous agents. In this study, Garcinia kola seed (GKS), Honey or a mixture of both were investigated for protective action against Cadmium-induced Hepatotoxicity in wistar albino rats. Different groups of the animals were fed GKS (of different dose regimen of 50mg/100g body weight and 100mg/100g body weight), honey or a mixture of both (of dose concentration of $50 \mathrm{mg} / 100 \mathrm{~g}$ body weight) for 14 days and then co-administered orally with cadmium acetate from the $14^{h}$ to $21^{\text {st }}$ day. Liver cell injury was assessed by the determination of plasma total and conjugated Bilirubin, aspartate aminotransferase (AST), alanine amino transaminase (ALT) and gamma Glutamyl transferase (GGT). Histological studies on the Liver was done for 3 rats in each group using Haematoxylin and eosin stain ( $H$ and $E$ stain), and their pictographs ( $x 400$ magnification) was reported. Results obtained showed that administration of cadmium acetate alone caused a significant increase ( $p<0.05)$ in plasma activities of the liver enzymes (AST, ALT and GGT) and total bilirubin concentration. These show that cadmium is a very poisonous and toxic Heavy metal. The histological findings in the liver showed a clear distortion and cell damage. GKS, Honey or a mixture of both were found to exhibit protective characteristics against cadmium- induced liver cell injury as evidenced by the ability of each test material to mitigate the increase in plasma activities of liver enzymes and total bilirubin concentration for the liver function markers. These findings were consistent with the results of the histological studies of the Liver from GKS and Honey fed rats.
\end{abstract}

Keywords: Garcinia kola Seed. Aspartate transaminase. Alanine transaminase. Gamma Glutamyl transferase, Cadmium

\section{Introduction}

Many researchers have reported on the therapeutic and protective potential of some traditional African herbs, roots, fruits and liquid substances against certain diseases, disorders and against toxic substances/heavy metal poisoning. It was noted that these traditional African food materials contain many biochemical and biomedical substances that have the potential to cure and treat many disease conditions. The traditional African medicines have long being in practice for more than 1000 years. The Medicines have been used in the treatment of Flu, Malaria, Tuberculosis, chest pains and cholera etc. Commonly used substances for such treatment include Pawpaw leaf, Tigernut, Garcinia kola Seed, Natural Honey, Aloe Vera plant and Mustard seed etc.

Heavy metal poisoning is listed among one of the major causes of death and health hazard worldwide. This is due to the excessive use and poor disposal without prior treatment. Many toxic substances have been reported to be harmful to humans in the past decades. These heavy metals have carcinogenic and poisonous effects. Heavy metals include lead, Chromium, Arsenic, Beryllium, Cobalt and Cadmium.

Cadmium is a known Carcinogenic agent (Jarup, 2007). It expresses toxicity by binding irreversibly to proteins and it enhances the release of free radicals such as hydrogen peroxide, hydroxide and superoxide anion thereby causing tissue damage (Thorne, 2008). Cadmium is a very toxic heavymetal and it is an important environmental pollutant in air, soil and water (Abdel-Monein, 2009). Cadmium has been considered as a risk factor for humans, as it accumulates in the body tissues, such as the liver, lungs, kidney, bones and reproductive organ (Sullivan et. al., 2009). Cadmium has been reported to generate reactive oxygen species causing oxidative damage in various tissues in the human system. Cadmium is a highly toxic heavy metal, and it has been classified as a human carcinogen. It has also been classified as carcinogen (class 1). Cadmium is not known to have any biological property or significance in humans (WHO expert Report, 2012). The liver and the kidney are considered the most vulnerable organs to cadmium toxicity in mammals (Abd- El Baset, 2012).

Garcinia kola seed, also called bitter kola in some traditional African communities is among the medicinal plants commonly used. It is within the family of Clusiacea. Garcinia kola (Heckel), an angiosperm, belonging to the family Guttiferae is known in commerce as bitter kola. On chewing, Garcinia kola seed has a bitter astringent and resinous taste, somewhat resembling that of raw coffee, followed by a slight sweetness. Bitter kola is a highly valued ingredient in African ethno medicine because of its varied and numerous uses which are social and medicinal; thus making the plant an essential ingredient in Folk medicine (Adesuyi et al., 2012). Garcinia kola seed has long been used in sub-Saharan Africa as an antidote for ingested poison, and as a cure for a number of ailments and conditions such as abdominal colicky pain, chest cold, cough and hepatitis (Iwu, 2000). The documented and suggested clinical uses of Garcinia kola seed include drug detoxification (Braide, 1990), liver disorder (Akintonwa and Essien, 1999) and boosting immune system (Okunji, 1999). 


\section{International Journal of Science and Research (IJSR) \\ ISSN (Online): 2319-7064}

Index Copernicus Value (2013): 6.14 | Impact Factor (2015): 6.391

Most researchers reported that the bioactivities of Garcinia kola seed are believed to be related to the presence of biflavonoids, which are well known antioxidants.

Honey is a natural sweetener (Cortes and Montenegro, 2010). It is the substance made when the nectar and sweet deposit from plants are gathered, modified and stored in the honey comb by honey bees (Singh 2010, and Sheeba, 2012). Evidence indicates that Honey can exert several health beneficial effects such as gastro protective, hepatoprotective, hypoglycemic, antioxidant, antihypertensive, antibacterial, antifungal, nephroprotective and anti-inflammatory effects (Erejuwa and Wahab, 2012). Honey is reported as a Novel antioxidant (Sheeba, 2011), which is known to have these effects because it is composed of fructose, proteins, ammo acids, vitamins, phenolic compounds, organic acids and multiple minerals. Honey is also known to be rich in flavonoids, which is a powerful antioxidant necessary for treatment of many infections. Honey is also rich in vitamin $\mathrm{C}$ and $\mathrm{E}$, which are potent antioxidants (FHIS, 2012).

The liver is known to be a complex organ responsible for many major metabolic functions in the body (Baker and Silverton, 1996). The liver is the largest in the body and from a metabolic stand point is the most complex. It is the main chemical factory of the body. One of the mainfunctions of the Liver is detoxification of drugs, poisons and toxins. Since drugs, poisons and toxic agents are known to be injurious to the Liver, the alleviating effect of Garcinia kola seed and Honey Mixture on Cadmium-induced liver toxicity was assessed by studying changes in the activities of marker enzymes and Liver histology which are diagnostic indicators of hepatotoxicity.

\section{Materials and Methods}

Laboratory Animals: A total of 30 albino rats were used for this study. The rats comprised of a mixture of males and females at discrete combination and were of weight 120$180 \mathrm{~g}$. They were purchased/obtained and kept in the animal house of the Department of Human Physiology, University Port Harcourt. The rats were kept in a spacious and wellventilated cage at Room temperature; under 12 hours light and dark cycle and acclimatized for 21 days. Three (3) weeks acclimatization period was allowed before initiation of the experiment. The cages were specially designed Laboratory cages and the animals were fed with a commercial rat diet (Top feed limited, Sapele, Nigeria) and clean drinking water ad libitum. All the animals received humane care according to the criteria outlined in the Guide for the Care and the Use of Laboratory Animals prepared by the National Academy of Science published by the National Institute of Health (NIH). The ethical regulations in accordance with National and Institutional guidelines for the protection of animals' welfare were strictly adhered to during the experiment (PHS, 1996).

Honey: The honey used was a pure commercial honey (Havillah Natural forest honey, NAFDAC Number 007654) bought from a local trader in Choba, Port Harcourt, Nigeria. It was diluted before use with distilled water on a weight/volume ratio of $1: 4$, i.e $25 \mathrm{~g}$ honey: $100 \mathrm{ml}$ Normal Saline. The Honey was correctly identified and authenticated by a worker of the Department of Human Physiology, University of Port Harcourt.

Plant Material: Seeds of Garcinia Kola seed were purchased from a local market at Choba, Port Harcourt, Nigeria. After removing the brown testa, the seeds were cut into small pieces, air- dried and then grinded into fine powder using an electric blender with mill (Qasa SD 230 series). Twenty five grammes $(25 \mathrm{~g})$ of the pulverized seeds were mixed with $100 \mathrm{ml}$ of Normal Saline at a weight/ volume ratio of 1:4. They were correctly identified and authenticated in the Herbarium Unit of the Department of Plant Science and Technology, University of Port Harcourt.

For the preparation of Honey and Garcinia kola seed mixture, $20 \mathrm{~g}$ of the powdered seed was added to $80 \mathrm{~g}$ of Honey. The mixture was diluted with Normal Saline at a weight/volume ratio of 1:4.

Chemicals: Cadmium acetate was obtained from the postgraduate research Laboratory, Dept. of Biochemistry, University of Port Harcourt. All other chemicals used were of analytical grade.

Preparation of Cadmium Acetate Solution:About 50g of the cadmium acetate salt was measured from the pack and kept dried. To prepare the working solution, $20 \mathrm{~g}$ of Cadmium acetate salt was weighed and diluted with $100 \mathrm{ml}$ of Normal Saline. The preparation was allowed to fully dissolve before usage.

Hepatoprotective Study: At the end of the acclimatization period, the animals were divided into Eight (8) equal groups of five rats each.

Group I served as the Normal/NegativeControl group.

\section{Group I; Normal Control}

Group I Rats received orally $0.5 \mathrm{ml} / 100 \mathrm{~g}$ body weight of Normal Saline once a day.

\section{Group II (Positive Control)}

Rats were fed orally daily with $200 \mathrm{mg} / \mathrm{kg}$ cadmium Acetate once a day for two weeks (14 days) (Satarug and Moore, 2004).

\section{Group III}

Rats in this group received orally $50 \mathrm{mg} / 100 \mathrm{~g}$ body weight of Garcinia kola Seed at a constant volume $0.2 \mathrm{ml} / 100 \mathrm{~g}$ body weight for 14days and then treated with cadmium acetate $\left(200 \mathrm{mg} / \mathrm{kg}\right.$ ofBody weight from the $14^{\text {th }}$ to $21^{\text {st }}$ day).

\section{Group IV}

Rats in this group received orally $100 \mathrm{mg} / 100 \mathrm{~g}$ body weight of Garcinia kola Seed at a constant volume of $0.4 \mathrm{ml} / 100 \mathrm{~g}$ body weight for 14 days and then treated with cadmium acetate $\left(200 \mathrm{mg} / \mathrm{kg}\right.$ body weight from the $14^{\text {th }}$ to $21^{\text {st }}$ day).

\section{Group V}

Rats in this group were administered with Garcinia kola Seed mixed with honey $(50 \mathrm{mg} / 100 \mathrm{~g}$ body weight) at a constant volume of $0.2 \mathrm{ml} / 100 \mathrm{~g}$ body weight) for 14 daysand then treated with Cadmium acetate $(200 \mathrm{mg} / \mathrm{kg}$ body weight from the $14^{\text {th }}$ to $21^{\text {st }}$ day). 


\section{International Journal of Science and Research (IJSR) \\ ISSN (Online): 2319-7064 \\ Index Copernicus Value (2013): 6.14 | Impact Factor (2015): 6.391}

\section{Group VI}

Rats in this groupreceived orally honey $(50 \mathrm{mg} / 100 \mathrm{~g}$ body weight) at a constant volume of $0.2 \mathrm{ml} / 100 \mathrm{~g}$ of body weight for 14 days and then treated with cadmium acetate ( $200 \mathrm{mg} / \mathrm{kg}$ body weight from the $14^{\text {th }}$ day to $21^{\text {st }}$ day).

At the end of the experimental period, the animals were fasted for 6hours and then sacrificed under chloroform anesthesia. After each sacrifice, blood was collected by cardiac puncture. About $7 \mathrm{mls}$ of Blood samples were collected into a Lithium Heparin bottle and the plasma obtained by centrifuging at $3,000 \mathrm{rpm}$ for $5 \mathrm{mins}$ in an automated centrifuge (Model AU 380). Then the plasma obtained was stored in a dry bijou bottle in a fridge and used for Hepatoprotective study.

The Liver Function Profile includes plasma Bilirubin (Total Bilirubin and Conjugated Bilirubin), Alanine transaminase (ALT), Aspartate transaminase (AST), and Gamma Glutamyl transferase (GGT).

Plasma Bilirubin was analyzed using the Jendrassik and Grof method (1937). The principle states that Bilirubin reacts with sulphanilic acid to yield a blue colour (Azobilirubin), and the intensity of colour is proportional to amount/ concentration of bilirubin. The absorbance was read at $600 \mathrm{~nm}$ for total, and $540 \mathrm{~nm}$ for conjugated Bilirubin.

Alanine and Aspartate transaminases (ALT \& AST) were analyzed using Frankel and Reitman Automated Method (1954). It is an end point enzymatic reaction using Coultel Automated machine system.

Gamma Glutamyl transferase (GGT) was analyzed using the Somongyi Method (1955).This method was done using the automated system. The automated system machine used for ALT, AST and GGT is called Automation system (MINDRAY BS $800 \mathrm{M}$ ).It was ensured that all procedure followed Standard Operational Procedure for Practice.

All analysis were done in the Chemical Pathology Department, University of Port Harcourt Teaching Hospital.
Histological Study: Three rats from each group were picked for histological study. The Liver of each rat was collected via abdomino-thoracic dissection into plain bottle containing formalin. The harvested organ (Liver) which was collected into plain bottle filled with formalin was sent to the Histology Laboratory, Department of Anatomy, and University of Port Harcourt. The organ was fixed, processed, sectioned, stained using Haematoxylin and eosin and the photomicrographs were prepared and interpreted

Statistical Analysis: The results were analyzed using the ANOVA Method and presented as Mean \pm SEM at $\mathrm{P} \leq 0.05$. Post hoc test (Tukey, LSD, Sheffe and Duncan) were used for multiple comparison (SPSS Version 18).

\section{Results}

The effects of Garcinia kola Seed (GKS), Honey or a mixture of both on plasma total \& conjugated bilirubin concentration and activities of three liver marker enzymes in Cadmium-treated rats are shown in Tables 1 to3. For the group fed with Cadmium alone, there was a significant increase in Plasma Total Bilirubin, Aspartate transaminase and Alanine transaminase as compared to the negative control. This showed that Cadmium expresses Hepatotoxicity in rats. For the group fed Garcinia kola Seed at $50 \mathrm{mg}$ or $100 \mathrm{mg} / 100 \mathrm{~g}$ body weight and Cadmium, there was a significant decrease in Plasma Total Bilirubin, Aspartate transaminase and Gamma glutamyl transferase as compared to the positiveControl (Cadmium fed group). There was however increase in plasma alanine transaminase activity of the Garcinia kola fed group when compared to the Cadmium group. Similarly, for the rats fed with Garcinia kola Seed mixed with Honey and Cadmium, there was a significant decrease in Total Bilirubin, Conjugated Bilirubin, Gamma glutamyl transferase and Aspartate transaminase. There was also an increase in Alanine transaminase as compared to the Cadmium only group. The same result was observed in the group fed with Honey and Cadmium. These results portray that Honey and the mixture of Garcinia kola Seed and honey posses hepatoprotective action against Cadmium induced hepatotoxicity.

Table 1: Effect of Garcinia kola Seed (GKS) on some Liver Function indices of Rats fed Cadmium (Cd)

\begin{tabular}{|c|c|c|c|c|}
\hline Indices & Normal Control & Cadmium only & GKS $_{1}$ plus Cadmium & GKS $_{2}$ plus Cadmium \\
\hline Total Bilirubin (Umol/1) & $6.60 \pm 0.40^{\mathrm{a}}$ & $28.40 \pm 0.51^{\mathrm{b}}$ & $12.60 \pm 0.81^{\mathrm{c}}$ & $10.81 \pm 0.49^{\mathrm{d}}$ \\
\hline Conjugated Bilirubin (Umol/l) & $0.000^{\mathrm{a}}$ & $14.40 \pm 0.75^{\mathrm{b}}$ & $2.00 \pm 0.32^{\mathrm{c}}$ & $1.00 \pm 0.45^{\mathrm{d}}$ \\
\hline AST (IU/1) & $344.00 \pm 41.5^{\mathrm{a}}$ & $1404.00 \pm 157.15^{\mathrm{b}}$ & $1098 \pm 39.80^{\mathrm{c}}$ & $788 \pm 25.02^{\mathrm{d}}$ \\
\hline ALT (IU/l) & $124.00 \pm 15.03^{\mathrm{a}}$ & $390.00 \pm 52.99^{\mathrm{b}}$ & $502 \pm 50.44^{\mathrm{b}}$ & $269 \pm 115.73^{\mathrm{c}}$ \\
\hline GGT (IU/1) & $4.42 \pm 0.11^{\mathrm{a}}$ & $8.52 \pm 1.68^{\mathrm{b}}$ & $7.46 \pm 0.73^{\mathrm{c}}$ & $6.68 \pm 1.25^{\mathrm{d}}$ \\
\hline
\end{tabular}

All values are expressed as Mean \pm SEM for 5 rats. Where:

- $\mathrm{GKS}_{1}=50 \mathrm{mg} / 100 \mathrm{~g}$ body weight Garcinia kola Seed.

- $\mathrm{GKS}_{2}=100 \mathrm{mg} / 100 \mathrm{~g}$ body weight Garcinia kola Seed.

- $\mathrm{AST}=$ Aspartate transaminase.

- $\mathrm{ALT}=$ Alanine transaminase.

- GGT= Gamma Glutamyl transferase.

The superscripts a, b, c and d represent statistically significant Groups.
Table 2: Effect of Honey on some Liver Function indices of rats fed Cadmium $(\mathrm{Cd})$.

\begin{tabular}{|c|c|c|c|}
\hline Indices & $\begin{array}{c}\text { Normal } \\
\text { Control }\end{array}$ & $\begin{array}{c}\text { Cadmium } \\
\text { Only }\end{array}$ & $\begin{array}{c}\text { Honey plus } \\
\text { Cadmium. }\end{array}$ \\
\hline $\begin{array}{c}\text { Total Bilirubin } \\
\text { (Umo/ll) }\end{array}$ & $6.60 \pm 0.40^{\mathrm{a}}$ & $28.40 \pm 0.51^{\mathrm{b}}$ & $9.20 \pm 0.37^{\mathrm{c}}$ \\
\hline $\begin{array}{c}\text { Conjugated } \\
\text { Bilirubin (Umol/l) }\end{array}$ & $0.000^{\mathrm{a}}$ & $14.40 \pm 0.75^{\mathrm{b}}$ & $0.80 \pm 0.37^{\mathrm{c}}$ \\
\hline AST (IU/l). & $344.0 \pm 41.55^{\mathrm{a}}$ & $1404 \pm 157.15^{\mathrm{b}}$ & $906.80 \pm 130.66^{\mathrm{c}}$ \\
\hline ALT (IU/l) & $124.00 \pm 15.03^{\mathrm{a}}$ & $390.0 \pm 52.99^{\mathrm{b}}$ & $473.0 \pm 110.79^{\mathrm{b}}$ \\
\hline GG GGT (IU/l) & $4.42 \pm 0.11^{\mathrm{a}}$ & $8.52 \pm 1.68^{\mathrm{b}}$ & $6.20 \pm 1.21^{\mathrm{c}}$ \\
\hline
\end{tabular}

All values are expressed as Mean \pm SEM for 5 rats. 


\section{International Journal of Science and Research (IJSR) \\ ISSN (Online): 2319-7064}

Index Copernicus Value (2013): 6.14 | Impact Factor (2015): 6.391

Where:

- $\mathrm{AST}=$ Aspartate transaminase.

- $\mathrm{ALT}=$ Alanine transaminase.
- GGT= Gamma Glutamyl transferase. Note the superscripts $\mathrm{a}, \mathrm{b}, \mathrm{c}$ and $\mathrm{d}$ represents statistically significant groups.

Table 3: Effect of Garcinia kolaSeed mixed with Honey on some Liver function indices of rats fed Cadmium.

\begin{tabular}{|c|c|c|c|}
\hline Indices & Normal Control & Cadmium only & GKS mixed with Honey \\
\hline Total Bilirubin (Umol/l) & $6.60 \pm 0.40^{\mathrm{a}}$ & $28.40 \pm 0.51^{\mathrm{b}}$ & $10.80 \pm 0.58^{\mathrm{c}}$ \\
\hline Conjugated Bilirubin (Umol/l) & $0.000^{\mathrm{a}}$ & $14.40 \pm 0.75^{\mathrm{b}}$ & $1.40 \pm 0.40^{\mathrm{c}}$ \\
\hline AST (IU//) & $344 \pm 41.55^{\mathrm{a}}$ & $1404 \pm 157.15^{\mathrm{b}}$ & $1238.80 \pm 251.81^{\mathrm{c}}$ \\
\hline ALT (IU/l) & $124.0 \pm 15.03^{\mathrm{a}}$ & $390.0 \pm 52.99^{\mathrm{b}}$ & $655.0 \pm 193.86^{\mathrm{b}}$ \\
\hline GGT (IU/l) & $4.42 \pm 0.11^{\mathrm{a}}$ & $8.52 \pm 1.68^{\mathrm{a}}$ & $6.20 \pm 1.21^{\mathrm{a}}$ \\
\hline
\end{tabular}

All values are expressed as Mean \pm SEM for 5 rats.

Where:

- GKS mixed with Honey is Garcinia kola Seed mixture with Honey.

- $\mathrm{AST}=$ Aspartate transaminase.

- $\mathrm{ALT}=$ Alanine transaminase.

- GGT= Gamma Glutamyl transferase.

Note the superscripts a, b, c and d represent statistically significant groups.

\section{- Histological Presentation}

The histological Presentation of the Liver cells are shown below. The Liver cells were stained with Haematoxylin and Eosin, and their Micro pictograph reported at $\times 400$ Magnification.
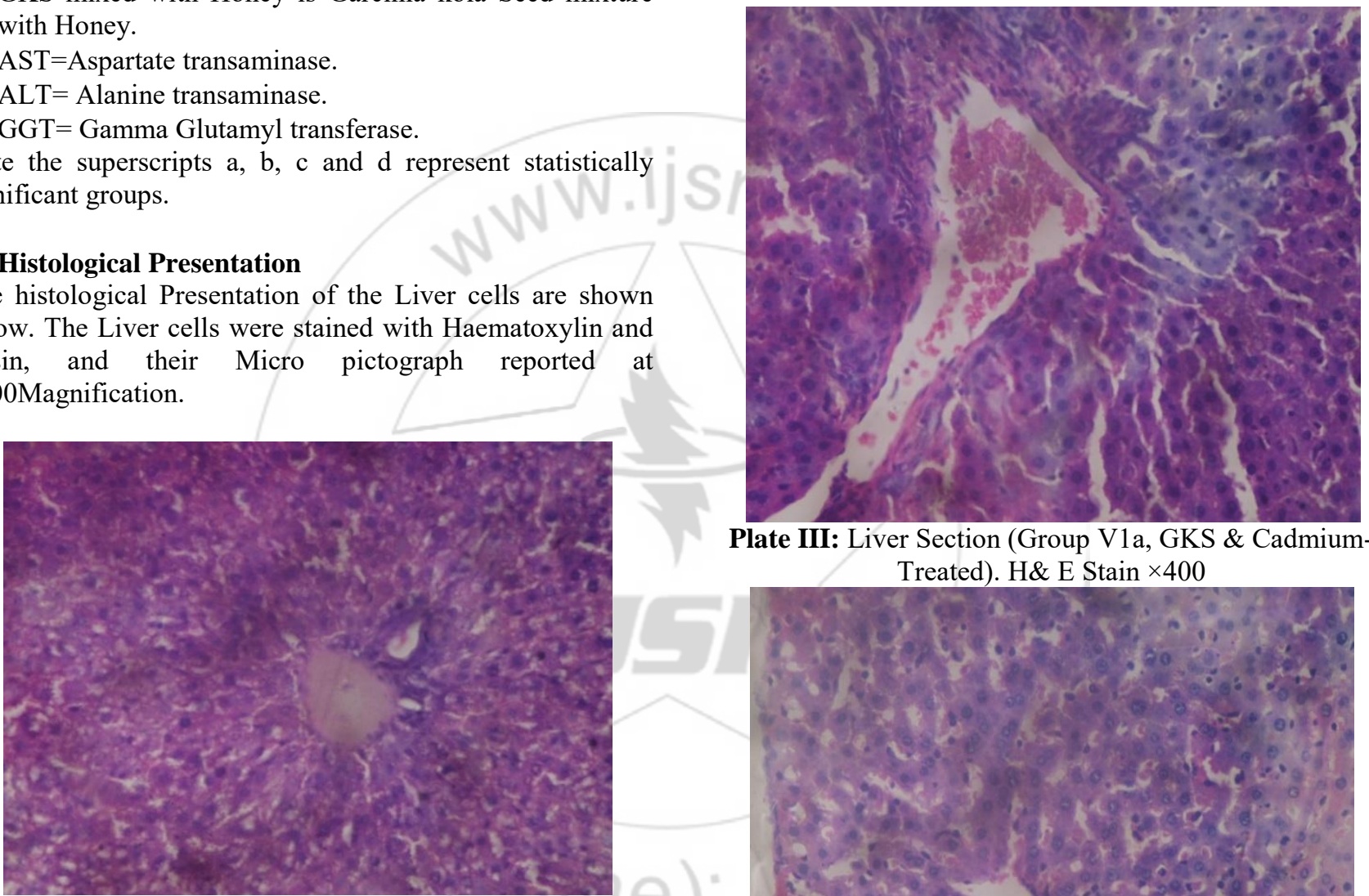

Plate III: Liver Section (Group V1a, GKS \& CadmiumTreated). H\& E Stain $\times 400$

Plate 1: Liver Section (Group V, Control). H\& E Stain $\times 400$
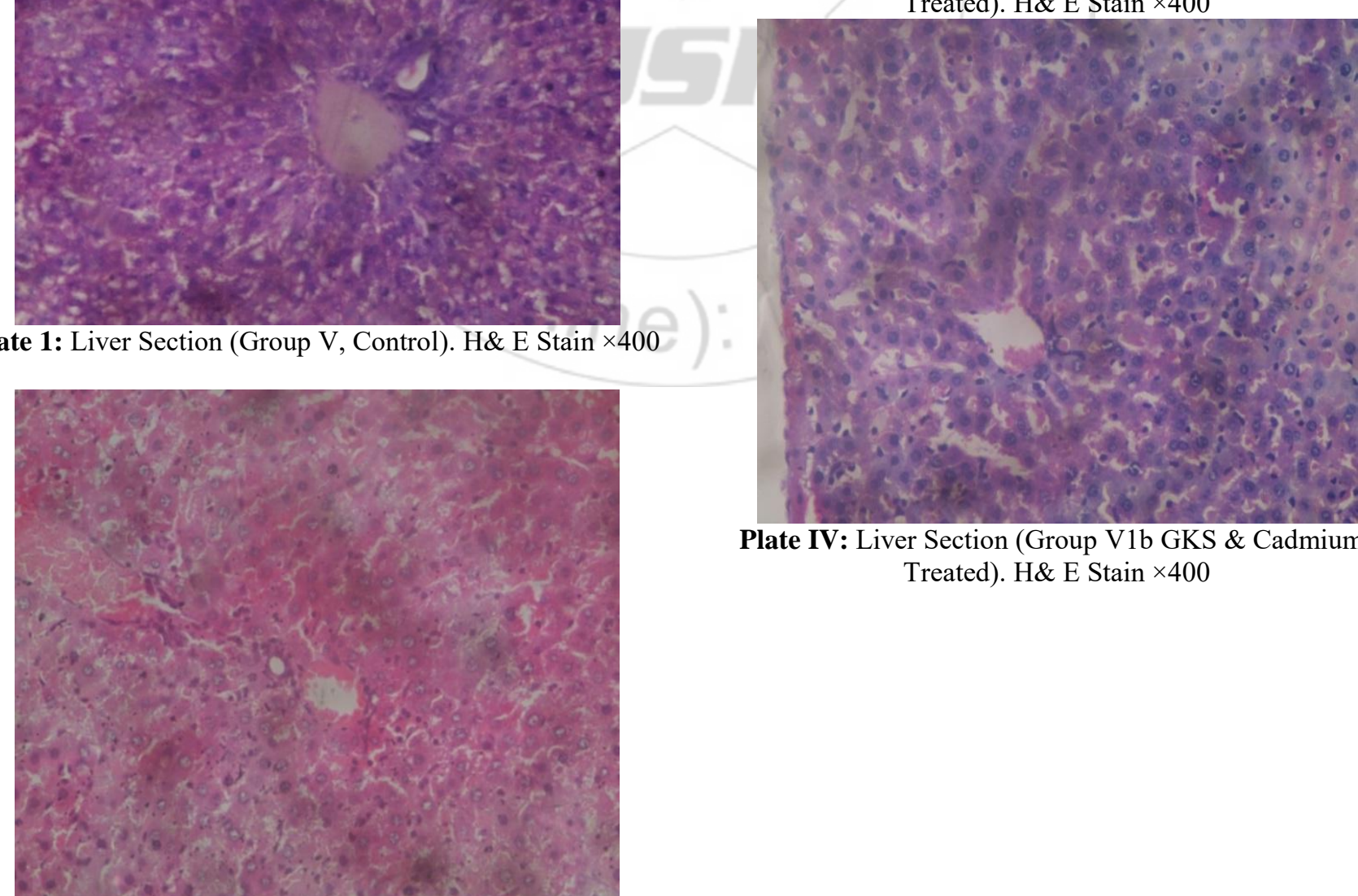

Plate IV: Liver Section (Group V1b GKS \& CadmiumTreated). H\& E Stain $\times 400$

Plate II: Liver Section (Group IV, Cadmium-Treated). H\&

E Stain $\times 400$ 


\section{International Journal of Science and Research (IJSR) \\ ISSN (Online): 2319-7064}

Index Copernicus Value (2013): 6.14 | Impact Factor (2015): 6.391



Plate V: Liver Section (Group VII GKS Mixed With Honey $\&$ Cadmium-Treated) H\& E Stain $\times 40$

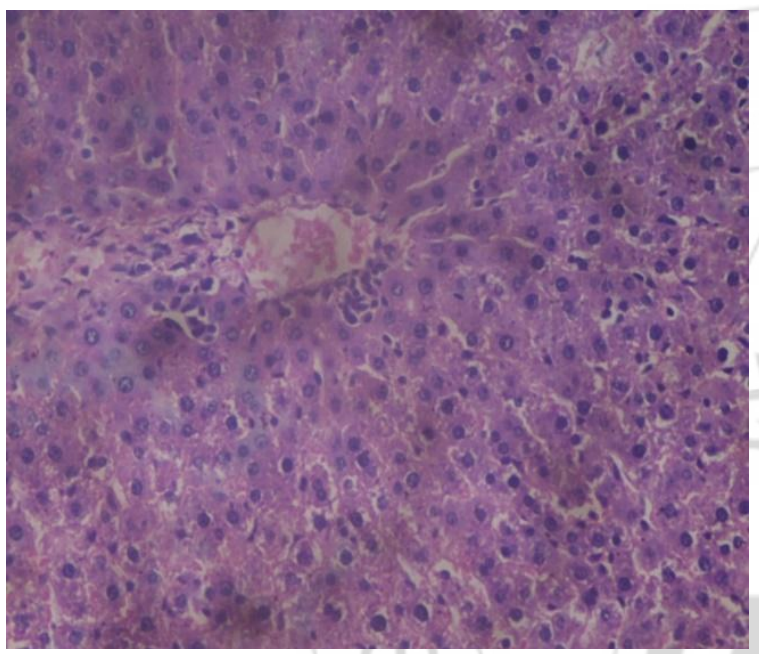

Plate VI: Liver Section (Group VIII Honey \& CadmiumTreated). H\& E Stain $\times 400$

\section{Plate I}

The liver cell showed the normal arrangement of the parenchymal of the Liver. The sinusoids were radially arranged from the central vein. Hexagonal shape of the Hepatocytes was maintained with viable hepatic cells. The control liver showed a normal architecture. There was also visibly evident a well-aligned cellular matrix. There was no infiltration or cellular distortion. The portal tract was devoid of debris and immune cells.

The Liver cells were intact and showed normal outline and maintained cellular integrity.

\section{Plate II:}

The rats received Cadmium acetate. The Liver cells of these animals showed obvious histological changes, in the form of distortion in the hepatic organization, dilation and congestion of the blood sinusoids and central vein. Some hepatocytes showed signs of degeneration in the form of hypertrophy with highly vacuolated cytoplasm and deeply stained nuclei. However, the Liver cells also showed a clear disruption of the sinusoid matrix and there was clear cell degeneration. The Liver cells showed the presence of Erythroid and immune cells. This was a clear indication of inflammatory response.
The Liver cells showed degeneration and inflammation due to Cadmium hepatotoxicity.

\section{Plate III:}

The rats received Garcinia kola seed (GKS) and Cadmium at a Garcinia kola Seed dose concentration of $50 \mathrm{mg} / 100 \mathrm{~g}$ body weight and then $100 \mathrm{mg} / 100 \mathrm{~g}$ body weight. The Liver cells appeared more or less similar to the control apart from few encroached portal tract and appearance of inflamed sinusoid. This showed that Garcinia kola Seed exhibited Protective effect against Cadmium Poisoning.

The Liver cells were intact and stable.

\section{Plate IV:}

The Liver cells showed portal tract encroachment with accumulated debris. This was an indication of cellular inflammation. The Liver cells exhibited an enlarged space of Disse. The Liver cells showed no degeneration or cellular matrix destruction. The Liver cells were intact and maintained cellular structure. This shows that a high dose of Garcinia kola seed portrays a protective effect against Cadmium poisoning.

Plate V:

The Liver cells showed an accumulation of Cellular debris in the portal tract. There was a clear evidence of Cellular Poisoning and Inflammation. A mixture of Garcinia kola Seed with Honey exhibited cellular damage and was less effective as a protective agent.

The Liver cells were intact and stable.

\section{Plate VI:}

The Hepatocytes appeared more or less similar to that of the Control apart from few hepatocytes appearing with vacuolated cytoplasm, and accumulation of cellular debris. The Liver cells showed disruption of cellular matrix. The Liver cells were intact and secured from Poisoning. Honey thus exhibited Protective effect against Cadmium Poisoning.

\section{Discussion}

The Liver is known to perform different kinds of Biochemical, synthetic and excretory functions, so no single biochemical test should be used to detect the function or damage of the Liver (Thapa and Walia, 2007).In this study, both the Biochemical \& Histological studies were used Available literature indicates no previous studies done to evaluate the antioxidant capacity of a mixture of Garcinia kola seed and honey, and its protective effect against cadmium intoxication. However, there are few literatures stating the antioxidant capacity of honey and its protective effect against cadmium toxicity in the liver (Abdel-Moneim and Wafaa, (2010)), and The Protective effect of Garcinia kola Seed, Honey and a mixture of both against Paracetamol-induced Liver toxicity (Eminedoki et al., 2010).

Epidemiological studies have revealed that Cadmium is one of the most toxic Heavy Metals to Humans(Abdel-Moneim and Wafaa, 2010). The mechanisms of cadmium-induced damage include the production of free radicals that alter mitochondrial activity and genetic information (Patrick 2003 


\section{International Journal of Science and Research (IJSR) \\ ISSN (Online): 2319-7064 \\ Index Copernicus Value (2013): 6.14 | Impact Factor (2015): 6.391}

and De Burbureet al., 2006). Cadmium is a known human carcinogen and one of its source is in tobacco and fertilizer source which together with water and food contamination represent the main source of non-occupational exposure in the general population (Ortega et al., 1998). It has been shown in many studies that cadmium induces oxidative damage by producing reactive oxygen species (Liu et al., 2008 and Chen et al., 2009). Cadmium has been reported also to cause damage to lipids and by that generates lipid peroxidation. Once taken up by the blood, the majority of cadmium is transported bound to sulfhydryl group containing proteins, such as albumin and metallothionein. About 30\% deposit in the liver and $30 \%$ in the kidney with the rest distributed 'throughout the body, with a clearance half- life of 25 years. (Wiksonet al., 2005). The half-life of cadmium in the blood has been estimated at 77-128 days. The first organ reached after uptake into the Gastrointestinal tract is the liver. Here cadmium induces the production of metallothionein. After consecutive hepatocyte necrosis and apoptosis, cadmium-metallothionein complexes are washed into sinusoidal blood. From here, part of the absorbed cadmium enters the intestine through the liver via secretion into the biliary tract in the form of cadmiumglutathione conjugates. The main organ for long term cadmium accumulation is the kidney and Liver. (Coy et al., 2007 and Nawrot 2005).

From the group fed Cadmium Acetate only; there was significant increase in total Bilirubin (TB), aspartate transaminase (AST) and Alanine Transaminase (ALT). The extent of liver cell damage caused by hepatotoxic agents is often assessed by the determination of plasma concentration or activities of a number of biochemical markers such as TB, AST and ALT (Dobbs et al., 2003 and Fody 2008). From this study, administration of cadmium acetate produced liver damage in rats as manifested by rise in TB, AST, ALT and other marker enzymes as compared to the control. These findings are in agreement with the results of many researchers that reported increase in AST, ALT and total Bilirubin concentrations in animals treated with hepatotoxic doses of cadmium (Shati 2000 and Ojo et al., 2006). Cadmium has no known role in normal human physiology. Cadmium forms protein-cadmium adducts. These are believed to exhibit cadmium toxicity via duration of the cadmium-bound proteins, resulting in a loss of function (Thorne 2006). The findings from data obtained in this study indicate that rats fed Garcinia kola Seed at different dose regimen $(50 \mathrm{mg} / 100 \mathrm{~g}$ body weight and $100 \mathrm{mg} / 100 \mathrm{~g}$ body weight) and cadmium shows that there were significant changes in the Liver Function markers as compared to the control. In the first dose regimen of Garcinia Kola Seed (50mg/100g body weight) there was a significant decrease in Plasma Total Bilirubin, AST activity and ALT activity as compared to the control. Also, in the $2^{\text {nd }}$ dose regimen (Garcinia Kola Seed) 100mg/100g body weight, there was a significant decrease in the biochemical parameters as compared to the control. These findings show that Garcinia kola Seed confers significant protection to the liver poisoned by cadmium. The findings are similar to those of other researchers (Braide et al., 2000; Abdel-Monein and Wafaa, 2007). These researchers reported that Garcinia kola seed is a very powerful food substance that is rich in phytochemicals and biflavonoids which are a potent remedy and protection against Cadmium-Induced Hepatotoxicity The Phytochemical Composition of Garcinia kola Seed shows that it is rich in micronutrients, phytochemicals (flavonoids and Cardiac glycosides) and carbohydrates which can be used as supplement that can prevent disease (Adesuyi, et al., 2013). Garcinia kola has been reported for the treatment of liver diseases (Iwu et al., 1990; Braide et al., 1991; and Terashima, 2007).The result obtained from the group fed Honey and Cadmium revealed that Honey portrayed Hepatoprotective effect against Cadmium Poisoning. This data were the same as revealed by (AbdelMoneim and Wafaa 2007) who reported that Honey exhibited protective effect against Cadmium Poisoning. Honey has been reported to be rich in bioflavonoids (Querticin and phenol), micronutrients (copper $(\mathrm{Cu})$ and Zinc (Zn), Fructose and Vitamins (Vitamin A, C and E). This is believed to be the source by which Honey exhibits its Protective effect against cadmium poisoning. However, chronic consumption of Honey has been reported to cause liver cell damage (Umokoroet. al., 2011). So, care must be taken in its consumption. However, in this study, Honey renders Protective effect against Cadmium-Induced Hepatotoxicity. The data obtained from the group fed a Mixture of Garcinia kola seed with Honey and Cadmium exhibited also a Protective effect against Cadmium Toxicity. The Combination of Garcinia kola seed and Honey is believed to be rich in bioflavonoids and phenolic compounds. This is believed to be the reason for its Hepatoprotective effect. This is same as reported by (Eminedoki et. al, 2001). Finally, the likely interpretation of the findings on the liver function parameters may be due to the presence of bioflavonoids and antioxidants in GKS and Honey. From these findings, a mixture of Garcinia kola seed and honey can be said to exhibit Hepatoprotective effect against cadmium poisoning.

Histological studies show that rats fed Garcinia kola Seed and Normal Saline (Control Group) had normal cell architecture of the liver as compared with Control. For the group fed Cadmium only, there was a clear distortion in cellular matrix. For rats fed Garcinia kola Seed at different doses with Cadmium, there was slight distortion in cellular matrix and encroached portal tract but the cell structure was intact. These findings suggest that Garcinia kola Seed exhibited Protective effect against Cadmium-Induced Hepatotoxicity. For the group fed Honey and Cadmium, the cell structure were intact without any disintegration. These findings also agree that Honey portrays a Hepatoprotective effect. The same is observed with the mixture of Garcinia kola seed with Honey and Cadmium.

\section{Conclusion}

In conclusion, the results of this study demonstrated that Garcinia kola Seed (GKS), Honey or a mixture of both acted as anti-hepatotoxic agent because each test material was able to significantly $(\mathrm{P}<0.05)$ reduce the elevated Plasma Total Bilirubin Concentration and Enzyme activities for the Liver function markers in rats exposed to Cadmium acetate treatment. These findings were further expressed in the histological studies that Garcinia kola seed, Honey and a mixture of both acted as anti-toxic agent in the liver. The observed anti-toxic activity might be linked to the presence 


\section{International Journal of Science and Research (IJSR) \\ ISSN (Online): 2319-7064 \\ Index Copernicus Value (2013): 6.14 | Impact Factor (2015): 6.391}

of flavonoids and phenol in both Garcinia Kola Seed and Honey This study reveals that Garcinia kola Seed, Natural Honey and their mixture can be effective in treating various ailments as reported by Eminedoki et al., (2010), Braide et al., (2012) and Didia et al., (2007).

\section{Acknowledgement}

We wish to express our heartfelt gratitude to the H.O.D and staff of Department of Medical Laboratory Sciences, Rivers State University of Science and Technology for their great support towards the success of this project. We also wish to thank the H.O.D and staff of the Department of Chemical Pathology, University of Port Harcourt Teaching Hospital where this research work was done. Finally, we wish to say a big thank you to Dr Olurunfemi Joyce of the Department of Human Physiology, University of Port Harcourt.

\section{References}

[1] Abdel Baset., El-Serogy., Tawfik, M., Almadani, S.A. and Attiah, A. (2012) Assessment of Toxic Metals in coastal sediments of the Rosetta area, Mediterranean sea, Egypt, Egypt Medical Journal, 12(13): 113-119.

[2] Abdel-Moneim, W.M. and Ghafeer, H.H. (2007) The Potential Protective Effect of Natural Honey against Cadmium-induced Hepatotoxicity and Nephrotoxicity, Mansoura Journal of Forensic, Medical and Clinical Toxicology. Vol 15, No 2, 75-95.

[3] Adal, M.T. (2012) Heavy Metal Toxicity, Chemisphere, 11; 23-45.

[4] Adesuyi, A.O., Elumu, I.K., Adaramola F.B., and Nwokocha, A.G.M. (2012) Nutritional and Phytochemical Screening of Garcinia kola seed, African Journal of Food Science and Technology. 4, 9-14.

[5] Agada, P.O and Braide, V.B (2009) Effect of Dietary Garcinia Kola seed on Selected Serum Electrolytes and trace metals in male albino rats, Nigerian Journal of Physiological Science, 24 (1-2), 53-57

[6] Agency for Toxic Substances and Disease Registry (2000) Cadmium and Cancer. 2. 7440-43-9.

[7] Agency for Toxic Substances and Disease Registry. (1993) Public Health issues. 4. 7445-42-2

[8] Agency for Toxic Substances and Disease Registry. (1997) Toxicological Profile for Cadmium

[9] Ajibola, A., Chamunorwa, J.P. and Erlwanger, H.K (2012) Nutraceutical values of Natural Honey and its contribution to Health Health and wealth, Nutrition and Metabolism. 9, 61-75.

[10] Akerele, O (1993). Summary of WHO guidelines for the assessment of herbal medicine. Herbals Gram, 28, 13-19

[11] Akesson, A., Berglund, M., Schutz, A., Bjellerup, P.,Bremme, K and Vahter M. (2002) Cadmium exposure in Pregnancy and Lactation in Relation to Iron Status, American Journal of Public Health, 92, 284-287.

[12] Akintonwa, A. and Essien, A.R (1990) Protective effects of Garcinia kola seed extracts against Paracetamol-induced Hepatotoxicity in rats. Journal of Ethnopharmaco, 29, 207-211.
[13] Animal Testing and Experimentation. http:// www. Animal testing.com/downloads/animals.pdf.

[14] Asagba, S.O and Obi, F.O. (2004) Effect of Oral Cadmium Exposure on Renal Glomerular and Tubular functions on Rats. Journal of Applied Science Environmental Management, 8 (1), 29-32.

[15] Baker, T. and Silverton, M.A. (1998) Introduction to Medical Laboratory Technology. $7^{\text {th }}$ Ed. Oxford Publisher. Pp 103-154

[16] Benefits of Honey and Cinnamon. http://www. Honey benefits.com/honey.pdf

[17] Bishop S. (2003) Heavy Metals in Clinical Chemistry: Principles, Procedure, Correlations. $6^{\text {th }}$ edition Oxford Publications, London. Pp 208-220.

[18] Braide, V.B (1991) Inhibition of drugs metabolism by flavonoid extract (kolaviron of Garcinia kola seeds in the rats), Phototherapy Research, 5 (1):38-43.

[19] Burkill H. M, (1991) The Useful Plants of West Tropical Africa, Royal. 35. 2, 173-177

[20] Caciari, T., Sancini, A., Tomei, F.A., Antetomaso,T. L., Tomei, K. G., Scala, B.B., Sinibaldi, F., Di Pastena, C., Andreozzi, G., Nardone, N., Schifano, M.P., Corbosiero, P and Caposella, A.(2000) The Health Dangers of Cadmium, American Journal of Toxic Substance, 3, 24-28.

[21] Calixto, J.B (2005) the Useful Plants of West Tropical Africa. Cambridge Publisher $2^{\text {nd }}$ Edition. Pp 453-489

[22] Chank, R. 2003 Some Aspect of Toxic Contaminant in Herbal Remedies: A Review Chemosphere, 52, 13611371

[23] Cheesborough, M. (2000) District Laboratory Practise for Tropical Countries. Cambridge: Part 1 \& 2. Pp 5799.

[24] Chen, X., Wang, J., Shi, Y., Zhao, M.Q. and Chi, G.Y. (2011) Effects of Cadmium on growth and photosynthetic activities in pakchon and Mustard, Botanical sciences, 52:41-46.

[25] Cortes, M.E., Vigil P and Gloria Montenegro (2011) The Medicinal Value of Honey, CienciaInvestigacionAgraria Human Health, 38 (2), 303-317.

[26] Coy, P., Hudson, I., Payne, D.G., and Shen, T. (2001) The Effect of Cadmium acetate on thyroid function and fertility profile, International Oncology Biology, 2; 11-17.

[27] Crook, M.A. (2006) Trace Elements and Substances in Clinical Chemistry. Clinical Chemistry, 7th Edition. Cambridge, London. Pp 452-464.

[28] Deburbure, C. and Bernard, A. (2006) Prolactin Changes as a composure of Chemical exposure: Deburbure and Bernard Respond, American Journal of Toxicology, 114(10); 574-588.

[29] Didia, B.C and Wegwu, M.O (2007) Hepatoprotective effect of Garcinia kola seed against Carbon tetrachloride-induced in rats, Nigeria Society of Experimental Biology, 19(1): 17-21

[30] Dobbs, N.A., Twelves, C.J., Gregory, W., Cruickshanka, C., Richard, M.A and Rubens, R.D. (2003) Epirubin in patients with Liver dysfunction; Development and evaluation of a Novel dose modification scheme, Europe Journal of cancer, 39: 580-596. 


\section{International Journal of Science and Research (IJSR) \\ ISSN (Online): 2319-7064}

Index Copernicus Value (2013): 6.14 | Impact Factor (2015): 6.391

[31] Eminedoki, D.G., Uwakwe, .A.A and Ibe, G.O (2010) Effect of Garcinia kola Seed and Honey Mixture against Paracetamol-induced Hepatotoxicity in rats, Nigeria Journal of Biochemistry and Molecular Biology, 25(2), 1-8.

[32] Iwu, M.M. (1982) Traditional Igbo Medicine. Institute of African Studies, University of Nigeria, Nsukka Publishers, 2: 104-118.

[33] Jarup, L. (2003) Hazards of Heavy Metal Contamination, British Journal of Medicine, 68: 167182.

[34] Liu, S.U., Chung, T.C. and Lin, C.C. (2002) The Hepatoprotective effect of Solinumalatammoenchon acetaminophen-induced Hepatotoxicity in mice, American Journal of Clinical Pathology, 28: 105123.

[35] Nawrot, T.S., Staessen, J.A., Roels, H.A., Munters, E., Cuypers, H.J and Vangronsveld, J. (2010) Cadmium exposure in the population: From Health risk to strategies of Prevention, Bimetals, 23: 769-782.

[36] Ojo, O.O., Nadro, M.M and Tella, I.O (2006) Protection of rats by extracts of some common trees against acetaminophen-induced hepatotoxicity, African Journal of Biotechnology, 5(9): 755-761.

[37] Okunji, C., Komarnytsky, C., Feara, G., Poulev, A., Ribnicky, D.M., Awachie, P. I., Ito. Y AND Rashin, T. (2007) Preparation, isolation and identification of tyrosinase inhibitor from the seeds of Garcinia kola by High Speed Counter- Current Chromatography, Journal of Toxicology, 223(4): 554-567.

[38] Ortega-Villasante,C., Rellan-Allarez., Del Campo, F.F., Carpena-Ruiz, R.O and Hernadez, L.E. (2005) Cellular damage induced by Cadmium and Mercury in MedicagoSativa., Alternative Therapy of Health Medicine, 56(418):2239-2251.

[39] Patrick, B. and Lawal, T. (2003) Effect of Garcinia kola Seed on renal functions, Britianna Journal of Medicine, 2; 1102-1110.

[40] Public Health Services, PHS (1996) Alternative to Animal Testing, National Institute of Science, 4(2); 12-32.

[41] Shati, A.A. (2011) Effect of Origanummajorana L. on Cadmium-induced hepatotoxicity and nephrotoxicity in albino rats, Saudi Medical Journal, 32(8): 797-805.

[42] Sheeeba, V. G (2012) Nutritional and Phytochemical screening of Natural Honey, American Journal of Nutrition, 22(3):113-119.

[43] Singh, A., Bhat, T.K and Sharma, O. (2011) Clinical Biochemistry of Hepatotoxicity, Journal of Clinical Toxicity, 5: 26-37.

[44] Sullivan, K.R., Kazantis, G., and Lam, T.H. (1988) Mortality of Cadmium-exposed workers; a 5 Years update,PubMed, 14(14): 220-3.

[45] Terashima, H. (2005) Names, Uses and Attributes of Plants and animals among the Ituri Forest foragers: A comparative Ethnobotanical and Ethno zoological study, Botanical science; 12: 544-583.

[46] Thapa, B.R. and Walia, A. (2007) Liver Function Test and their interpretation, Indian Journal of Medicine, 74: 663-671.

[47] Thorne, D.P. (2007) Toxicology in Medicine, Oxford Publisher $6^{\text {th }}$ Edition, 587-603.
[48] Wilson, L. (2012) Cadmium; the Pseudo-masculine mineral and a death mineral, The Centre for Development, 3: 23-45. 